\title{
Prior to and in the Course of Covid-19 Pandemic: Exploring Learners' Experiences of Learning English through Narrative Lens
}

\author{
Achmad Kholili \\ Universitas Islam Zainul Hasan Genggong, Indonesia \\ achmadkholili93@gmail.com
}

\author{
ARTICLE HISTORY \\ Received : 9 May 2021 \\ Revised : 18 May 2021 \\ Accepted : 10 September 2021
}

\section{KEYWORDS}

Narrative Inquiry

EFL Learners' Experiences

Face-to-face Learning

Asynchronous Learning

Hybrid Learning

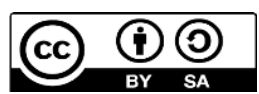

\begin{abstract}
The language learning largely took place in the classroom, especially prior to Covid-19 pandemic and that this occurrence resulted in simplicity for the learners to learn and interact with each other because they could directly make in contact with their classmates and their teachers. However, since the pandemic developed in March 2020, all the learning process was subsequently altered into online learning. To date, studies on language learning has been undertaken by the researchers both at intra and international level. Despite the existence of these former studies, little work reports the comprehensive picture of language learning experiences prior to and during Covid-19 pandemic. To fill this lacuna, the current article reports on a narrative inquiry of EFL learners' experiences of learning English prior to and during Covid-19 pandemic. Drawing upon data from a semi-structured interview with two Indonesian EFL learners of the sixth semester majoring in English education program, the finding indicates that EFL learners have sustained multifaceted learning experiences prior to and during the pandemic. They have gone through face-to-face learning prior to the pandemic, asynchronous learning during the pandemic and hybrid learning experience during the Covid-19 pandemic. This article concludes with suggestions for promoting hybrid learning model in the EFL setting, particularly in a higher education during the Covid-19 pandemic.
\end{abstract}

\section{Introduction}

The proliferation of teaching and learning of English has taken place all over the world including in Indonesia (Yulia, 2013). In the 21st century in particular, the process of teaching and learning English has occurred in the classroom for the most part (Sulistyo, 2016), leading learners to cooperate and interact with each other to communicate and learn. Nevertheless, this face-to-face learning has only lasted a moment; it turned immediately after the Covid-19 pandemic developed, particularly in March 2020 (Hussein, 2020) declared by World Health Organization (WHO). This Covid-19 pandemic has brought about a considerable impact in education across the globe (Dhawan, 2020; Osman, 2020), encouraging the government in Indonesia to offer alternative educational process for the learners (Abidah et al., 2020). As such, the government, afterwards, teamed up with other parties to come up with the workable solutions in effort to keep the learners learn during the pandemic. In so doing, online learning (Sing \& Thurman, 2019; Mishra et al., 2020; Konig et al., 2020) was subsequently proposed by them.

Due to the rapid development of technology, it has made the distance learning come in handy (McBrien et al., 2009) and therefore the teachers have subsequently kicked off adopting online learning software and applications so that their learners can keep learning with their instructors during the pandemic (Singh \& Thurman, 2019). The mobile applications utilised by the English teachers include, but not limited to Zoom (Dharma et al., 2017; Kohnke \& Moorhouse, 2020), Google Classroom (Octaberlina \& Muslimin, 2020), Moodle (Putri et al., 2020), Kahoot (Putri, 2019) Skype (Terhune, 2015; Jena, 2020), and WhatsApp (Awada, 2016; Al-Qahtani et al., 2018; Annamalai, 2019; Dahdal, 2020).

To date, studies on English language learning and teaching have been carried out both intra and international contexts, centring around investigating the students' emotion in language learning during the pandemic (Suprihatin et al., 2020), looking into the way the EFL teachers did English learning to their learners (Atmojo \& Nugroho, 2020), and delving into ESP teachers' strategies and their challenges during Covid-19 pandemic. In the meantime, language learning and teaching research during the pandemic were also undertaken overseas, ranging from looking into home-schooling learning experiences (Bub \& Jones, 2020), how teaching and learning can still go on during Covid-19 pandemic (Ali, 2020), and online teaching and learning process in a higher education (Mishra, 2020). 


\section{Literature Review}

Notwithstanding these previous studies, little attention has been attracted in terms of the exploration of language learning experiences by EFL learners in a higher education, especially within two phenomena at the same time, that is, prior to and during the Covid-19 pandemic, specifically in an Indonesian context. Therefore, this narrative methodology attempts to fill this void. This study is intentionally aimed to provide a holistic understanding with respect to learners' experiences and their negotiation while learning English prior to and in the course of the Covid-19 pandemic, especially this focus on the learning situation prior to and during the pandemic, the media used in learning English prior to and during the pandemic and the types of learning media employed prior to and during the pandemic at the Universitas Islam Zainul Hasan Genggong. Following this, the researcher subsequently posed two research questions: what learning experiences did the EFL learners have prior to the Covid-19 pandemic? And what learning experiences do the EFL learners encounter during the Covid-19 pandemic?

\subsection{Covid-19 Pandemic}

The coronavirus disease, henceforth Covid-19, has been documented as the fifth pandemic since the $1918 \mathrm{flu}$ pandemic. It initially developed in Wuhan, China and then spread widely in the world. It was officially named severe acute respiratory syndrome corona virus 2 (Sars Cov-2) by the International Committee on Taxonomy of Viruses based on the analysis of phylogenetic. Due to the fact that the virus is highly malignant, it subsequently seminated and constantly developed in the regions (Liu et al., 2020).

Indonesia, which is the fourth most populous country, has currently been affected by the Covid-19 and predicted to be happening over a longer period of time compared with other sparsely-populated country (Djalante et al., 2020; Liu et al., 2020). During December 2019 up to February 2020, no report was declared in Indonesia in terms of Covid-19 pandemic, only when it was on March 2nd 2020, The President, Joko Widodo, announced two main cases of Covid-19 infection (Djalante et al., 2020).

Since this is the case, the World Health Organization (WHO) has issued six strategies for copying with this disease. The strategies include the following: expand, train and deploy health-care workers; enact systems to find suspected cases; build up production of tests and increase availability; identify facilities that can be transformed into coronavirus health centres; devise plans to quarantine cases; and re-concentrate government measures on suppressing the virus.

\subsection{Online Learning as a Pandemic Necessity}

The swift development of technology has made the distance learning effortless (McBrain et al., 2009). Along with this, the utilization of technology in learning becomes indispensable. This is subsequently defined as online learning because the learners experience synchronous and asynchronous environments with different devices (Dhawan, 2020). These kinds of online learning cover the area of open learning, web-based learning, computer-mediated learning, blended learning, hybrid learning, and asynchronous online learning, and it therefore opens up possibilities to learn everywhere (Dhawan, 2020). These kinds of online learning are exploited differently by the teachers all over the world according to teachers' and students' needs.

In this pandemic era in particular, the use of technology becomes compulsory. The outbreak is serious and has forced the teachers and students to make use of online learning with technologies. Both teachers and learners were formerly reluctant to use technologies, and now they, on the other hand, have to accept the modern technology (Dhawan, 2020). Since the development of this outbreak, online learning has become a main need amidst the chaos (Islam, 2021; Putri et al., 2020). Therefore, the quality and requirement of this online learning and teaching at this stage is crucial. During this difficult time, the concern is not about whether the quality of teaching and learning method can supply quality education, but it is rather more emphasized on how the institutions, including Indonesia are able to adopt online learning massively (Carey, 2020).

\subsection{Studies on Using ICTs for Language Learning}

Information and Communication Technology (ICT) has been expounded as the manifold set of technological tools and resources employed to communicate, to create, disseminate, store, and manage the information (Ghashemi \& Hashemi, 2011). The use of ICT in language learning has been considered essential and it can produce the effective learning (Abidin et al., 2011). Besides it, ICT can also increase learners' motivation to learn (Grabe, 2005; Azmi, 2017). In the 21st century, ICTs are much employed for language learning in the EFL context. Shadiev \& Yang (2020) have listed technologies mostly utilized for language learning, some of which include game, corpus, automated feedback, social networking, instant messaging, virtual reality, websites and digital resources, speech recognition, collaborative writing tools, electronic gloss and annotation, intelligent tutoring systems, electronic dictionary, online video, e-books, video recording, augmented reality, robots, clicker, and wearable devices.

Former studies in language learning using ICTs in education have also been widely carried out over ten years ago. First of all, Chandra \& Yuyun (2018) have conducted a study on the effectiveness of Google Translate (GT) in EFL essay writing. Undertaken at Universitas Kristen Krida (Ukrida) Wacana, the study took eight respondents from Ukrida department of English. The data collected from mediated-observation and interview, assisted by screen-recording application. The results indicated that the students employed GT in three different aspects: vocabulary, grammar, and spelling. The highest utilization 
is on vocabulary, followed by a phrase, and sentenced as the third. Furthermore, spelling became the fourth highest exertion by the learners. In the meantime, grammar became the least employed by the learners. This means that the use of ICTs in language learning becomes increase. What's more, during this pandemic, the language learning is surely inseparable from utilizing the technology for distance learning. Google Translate (GT), Google Meet (GM) and other supporting media will be incredibly valuable. As such, this exploitation is of great value in education.

The next study was also carried out by Abdurrahman et al. (2018). In this regard, they conduct a study on the impact of using podcast on listening comprehension. This study took 60 high school learners in Indonesia. Using a quasi-experimental design with the post-test only control group design, the findings demonstrated that there is a significant difference of post-test score between two groups, favouring experimental group. Data analysis using one way ANOVA showed significance value (sig. 0.010) is lower than $<0.05$, which means that Podcast has a significant impact on learners' listening comprehension.

A study centering on technology was also conducted by Kheirzadeh \& Birgani (2018). They, in this case, attempted to show the effectiveness of blending learning platform (website and face-to-face) in improving learners' reading comprehension. 60 EFL learners were recruited in this study based on the convenience sampling. These participants were then divided into control and experimental group in which each group consists of 30 EFL students. The experimental group was asked to use the website nicenet.com at home, while control group was taught using traditional classroom. The findings showcased that blended learning had a positive effect on reading comprehension ability.

The phenomena before and during the pandemic in language education have occurred thus far. The process of language learning, for example, has shifted from face-toface to online learning. In the face-to-face learning, for instance, teachers in Indonesia have conducted a classroom teaching in which they were fully helped by media in the classroom such as laptop and LCD as an example (Idami, 2018). The study also stated that using these media could build a more conducive and vivid learning atmosphere. However, since the pandemic took place, the situation of learning had changed across all educational levels, including the level of university. The teachers and students must work online (Sing \& Thurman, 2019). The teachers need to teach English using technologies such as WhatsApp, Google Classroom, Zoom and many other technologies online from home and so do the students. This phenomenon has, however, been investigated by the researchers so far, one of which is investigating the students' perception between face-toface and online learning (Efriana, 2021; Setyaningsih, 2020). The results indicate that students perceived way better in face to face session than online learning and they also reported that online learning is more problematic (Efriana, 2021; Setyaningsih, 2020).

\section{Method}

Drawing on the poststructuralist view, the current study attempted to comprehend the learners' experiences in learning English prior and during Covid -19 pandemic. A narrative inquiry seems to best suit this since it deals with an experience as phenomena under study (Clandinin \& Rosiek, 2007). In this regard, the researcher tried to look for ways and portrayed the learners' experience learning English before and during Covid-19 pandemic through the stories they told (Clandinin \& Connelly, 2000; Creswell, 2005). As such, the researcher took narrative lens as a methodology for the current study, which assigned the learners to tell the stories of their storied lives.

\subsection{Participants}

In selecting the participants, the researcher took feasibility for the inclusion. The learners must have been learning English before and during the pandemic and are willing to be involved in the study. Only those who signed the research consent form became the research participants of this study. Therefore, there were two participants in this regard who were willing: Deny and Any (pseudonyms). Deny is a male student majoring in English Education department at Universitas Islam Zainul Hasan Genggong. He has learned English prior and during the outbreak. Any is a female student from the same department at the same University who has also studied English before and during the Covid-19 Pandemic. These two participants shared their learning experiences each other.

\subsection{Narrative Tool}

To have the students' learning experiences of learning English in the higher education, a semi-structured interview was employed by the researcher. The semistructured interview concentrated on the learners' learning experiences in English prior to and during the Covid-19 Pandemic. The following is the sample of the interview:

1. Can you tell me about your learning experiences before the pandemic?

2. What media employed by your teachers during the faceto-face session?

3. What experiences did you have in learning English when the pandemic started developing?

4. How were your feelings using WhatsApp in learning English during the pandemic?

5. What difficulties did you have in learning English using WhatsApp?

6. How long was the online learning applied?

7. What media used in the hybrid learning?

8. How were your feelings after using the media for language learning? 
In this session, the researcher allowed the participants to tell the stories of their language learning experiences prior to and during Covid-19 Pandemic. The two learners shared their learning experiences using English, displaying some grammatical errors shown in the interview extracts and it was however then revised by the researchers. This was done in order that the participants' statements of their learning experiences could be fully and easily understood. This interview lasted between 30-40 minutes and the researcher intended to minimize his personal reaction while conducting the interview so as to keep away from his influence on the stories they told. In other words, the researcher allowed the participants to tell whatever they have experienced in learning English prior to and during Covid-19 pandemic. The researcher utilized a tape recorder by agreement with the research participants in order not to miss the participants' stories. Furthermore, the researcher also took note of the observation during the interview so as to help me comprehend the situation and context of the participants stories (Polkinghorn, 2005).

\subsection{Trustworthiness}

In order to make sure the trustworthiness of the data (Lincoln \& Guba, 1985) and verification of the interview data, the researcher did participant validation or memberchecking by inviting the participants and asking them carefully read through the interview transcripts and/or data analysis for them to validate, or refute, or give feedbacks or comments on the researcher's interpretation of the data (Burnard et al., 2008). To be sure, this arguably helped to enhance the development of themes and theories. It is part of the relational responsibility of narrative inquiry (Clandinin \& Connelly, 2000), to negotiate anonymity, boundaries, and ethical issues with participants.

\subsection{Narrative Analysis}

Geared under a qualitative research design, a qualitative content analysis was utilized in this study. The fundamental components of the data analysis in qualitative paradigm pervade coding, categorizing, forming themes, and using constant comparative analysis. To begin with, the researcher gathered the entire transcript and each transcript was reexamined to compare concepts figured out in other transcripts, allowing constant comparative analysis to ascertain carefulness and thoroughness of the analysis. All codes were re-examined by the researcher to recognize related ideas which in turn formed concepts. The coded concepts were subsequently clustered to form categories, as they were continuously examined for apparent relatedness to each other. After they all fallen into categories, the data were re-examined and coded again to achieve a consistency of codes (Miles, Huberman, \& Saldana, 2013). The categories were then re-assembled under the relevant themes that emerged from roaming the categorized data. In order to make sure the reliability of coding, the researcher sought another researcher to code the same transcription. Following that, a discussion was generated as to the similarities and differences. During the coding process, as the researcher used the informant's own words and concluded their statements, both descriptive and in-vivo coding were drawn upon by the researcher (Saldana, 2015). The researcher attempts to account for the findings of the study by focusing primarily on the students' experiences of learning English pre and during Covid-19 pandemic. It encompasses Face-toface learning experience prior to Covid-19 Pandemic, Asynchronous learning experience during Covid-19 Pandemic, and Hybrid learning experience during Covid-19 pandemic.

\section{Results}

Within this section, the researcher re-narrates the learners' stories of learning experiences in English prior to and during Covid-19 Pandemic. In this case, the narratives of the learners' experiences include prior learning experiences or before the Covid-19 pandemic and during the Covid-19 pandemic. Their differences were portrayed in the coding results displayed in Table 1.

Table 1. Themes of learners' learning experiences prior to and during Covid-19 pandemic

\begin{tabular}{lll}
\hline $\begin{array}{c}\text { Face-to-face learning experience } \\
\text { prior to Covid-19 Pandemic }\end{array}$ & $\begin{array}{c}\text { Asynchronous learning } \\
\text { experience during Covid-19 } \\
\text { Pandemic }\end{array}$ & $\begin{array}{c}\text { Hybrid learning experience } \\
\text { during Covid-19 pandemic }\end{array}$ \\
\hline $\begin{array}{l}\text { Learning English using LCD and } \\
\text { laptop before the pandemic. }\end{array}$ & $\begin{array}{l}\text { Using WhatsApp for learning } \\
\text { English during the pandemic. }\end{array}$ & $\begin{array}{l}\text { Online and offline learning done in } \\
\text { the midst of Covid 19 Pandemic. }\end{array}$ \\
\hline $\begin{array}{l}\text { Ample opportunities for consulting } \\
\text { with their lecturers. }\end{array}$ & $\begin{array}{l}\text { Three features employed in } \\
\text { learning English: Videos, PPT, and } \\
\text { links of YouTube. }\end{array}$ & $\begin{array}{l}\text { Four learning media employed in } \\
\text { the online learning: WhatsApp, } \\
\text { Google Classroom, Zoom, and } \\
\text { Gmail, and two learning media } \\
\text { used in the offline learning: LCD } \\
\text { and Laptop. }\end{array}$ \\
\hline
\end{tabular}


Based on the interview analysis, three scenarios were found: face-to-face learning experience prior to Covid-19 pandemic, asynchronous learning experience during Covid-19 pandemic and hybrid-learning experience during the Covid-19 pandemic.

\subsection{Face-to-face learning experience prior to Covid- 19 Pandemic}

a. Learning English using LCD and laptop before the pandemic

In 2018, Deny and Any found that they dealt with face-to-face learning every day. They found this method way more accessible to them since they could interact and cooperate with their friends. They also experienced student-centred learning, for example, doing a presentation in front of their classmates, assisted by LCD and Laptop. As such, it had driven them to be a creative learner and motivated to practice and learn English in their daily life.

"I studied together with my friends when it was in 2018. It was so effective since my lecturer did a face-to-face learning using LCD and Laptop and applied a studentcentred approach in the teaching and learning process. When the presentation run and I was asked to perform English in front of my friends, I attempted to do my best by showing my skills in English. That made me more enthusiastic." (Deny, 2021)

Excerpt 1

"The class was very fun since we were asked to perform one by one in front of the class. Unforgettably, the lecturer also provided some materials or references to support the learning process so that we could get what the materials were. We were also allowed to share our ideas or addressing some questions for discussing the materials. This face-to-face learning made us more creatively and brought more enthusiastic." (Any, 2021)

Excerpt 2

With the student-centred approach, the learners perceived that they were so helpful that they were mediated by the use of LCD as a support of learning English in the classroom. They felt more facilitated at that time.

"I was quite facilitated in the learning process since the lecturers supplied LCD for additional facility in the learning process. They provided some videos and therefore it helped me more understood of the materials I learnt." (Deny, 2021)

\section{Excerpt 3}

"The learning process was very fun since the lecturers employed LCD for helping me in understanding materials. They also gave clear explanation by showing some videos so I learnt it very fun.” (Any, 2021)

Excerpt 4 b. Ample opportunities for consulting with their lecturers

Learning English offline (face-to-face learning) has made them satisfied. In fact, they could grasp ample opportunities to consult any materials with their lecturers and found exciting chances to speak English with their friends in the classroom. It made their learning progress much more satisfactorily and contributed significantly to their language skill in English. The lecturer assisted and improved them immediately after their learning practice so they could recognize the errors in the learning process.

\begin{abstract}
"It was easy to do because we had so much time to direct interaction with the lecturer and we still remembered when we did not understand some materials, we directly asked our lecturer about that. A clear explanation from the lecturer gave us a way to understand the materials much easier. Besides, I had much time to practice speaking with my friends at that time especially when the speaking subject was held.” (Deny, 2021)
\end{abstract}

Excerpt 5

"I could practice speaking with my friends directly and asked some feedback from my lecturer regarding whether or not there was an error, thereby making us easier to know and it developed my speaking skill." (Any, 2021)

Excerpt 6

\subsection{Asynchronous learning experience during Covid-19 Pandemic}

c. Using WhatsApp for learning English during the pandemic

The Covid-19 Pandemic has gradually influenced some sectors, including education in Indonesia. In this case, the shift in education was experienced by the learners in 2020 during the pandemic, in which it altered from offline to distance learning. In this case, the learning process was in the form of asynchronous model, assisted by WhatsApp application in the learning process and this lasted two semesters only in 2020. By using this app for language learning, it had brought them strength and weaknesses during the pandemic. The learners perceived that learning using WhatsApp could build their confidence as well as could generate their motivation to learn even though they also felt discomfort while staring at the platform for too long and looking at some superfluous materials posted within the group.

"By using WhatsApp as online learning during the Covid-19 pandemic in 2020, I felt motivated to learn and improved my confidence in the learning process. Also, I and my friends could share and ask immediately through the WhatsApp regarding materials we learned. However, the use of WhatsApp for language learning could drive us boredom since we must look at the screen for so long," (Deny, 2021)

Excerpt 7 
"Sometimes, I felt tedious using WhatsApp for too long in language learning because of the redundant posts posted in the group and looking at the posts or materials continuously. However, it is still okay for me rather than I have to learn with a laptop. Another benefit of learning English using this application was that I could ask my lecturer immediately whenever I had difficulties in the materials. Therefore, it could improve my motivation to learn English via WhatsApp. This activity happened in 2020 during the pandemic." (Any, 2021)

\section{Excerpt 8}

d. Three features employed in learning English: Learning Videos, PPT, and links of YouTube

The learners also reported that the learning covered sharing some learning videos, PPT, as well as links of YouTube for lesson. The learners learned English through texting and recording the voice note and share it on the WhatsApp. The submission of the tasks was also done through this platform. The learners felt easy to do that but they were sometimes upset for a large number of groups available in the platform they have.

"The learning of WhatsApp included sharing some learning videos, links of YouTube, as well as PPT from the teachers. The teachers used to share the links 10 minutes before the lesson begun.” (Deny, 2021)

Excerpt 9

"I and my friends used to prepare the lesson by sharing some learning videos or PPT when the presentation was held. The teachers also shared some PPT and explained them through WhatsApp. The information and submission of task was also done through this platform." (Any, 2021)

\section{Excerpt 10}

\subsection{Hybrid learning experience during Covid-19 pandemic}

e. Online and offline learning done in the midst of Covid 19 Pandemic

After using WhatsApp for about two semesters and the Covid-19 still continues developing, the stakeholders in the college afterwards shift the learning ways into hybrid learning. It is done in order to meet the students' needs since online learning with WhatsApp is felt tedious and needs a combination with real interaction and communication (face-to-face learning). Therefore, a combination of online and face-to-face learning (hybrid learning) is then adopted by them and the learners. The learners feel way better than ever in this hybrid learning process. The hybrid learning process has embarked on in the beginning of 2021 during the pandemic to date.

"The asynchronous learning has been practiced and experienced by the learners for about two semesters during the pandemic. However, my college then applies the different methods in learning, combining online learning with WhatsApp and face-to-face learning (hybrid learning); especially this starts in the beginning of 2021 in which the pandemic still continues developing. I think it is appropriate for us and more convenient than applying online learning only." (Deny, 2021)

Excerpt 11

"I feel that online learning is boring and we, as students, need to interact with each other like face-to-face learning. I have been thinking that the online learning will continue until the Covid-19 ends. However, my college then implements hybrid learning (online and face-to-face learning) in the learning process of English. Therefore, this combination has made us better in language learning. It brings a new experience for us in learning English especially in 2021 during the pandemic." (Any, 2021)

Excerpt 12

f. Four learning media employed in the online learning: WhatsApp, Google Classroom, Zoom, and Gmail, and two learning media used in the offline learning: LCD and Laptop

With the arrival of this hybrid learning, the learners felt far more motivated and more experienced with some learning media, such as WhatsApp, Google Classroom, Zoom, and Gmail used as a means of learning English during the pandemic.

"Since the hybrid learning is implemented by the lecturers, I felt more interested and more motivated to learn. The lecturers enhance my language learning through Zoom, WhatsApp and also combined with the classroom learning.” (Deny, 2021)

\section{Excerpt 13}

"When the hybrid learning is held by the lecturers, I and my friends gained valuable experience. The learning media used by the teachers in English learning have been variety, such as Zoom, Google classroom, Gmail, and WhatsApp. Besides this online learning, the lecturers also hold the classroom teaching and learning in the scheduled time using the LCD. Therefore, I felt more interested in learning English although the pandemic still go on developing." (Any, 2021)

Excerpt 14

The hybrid learning model (face-to-face method and online learning) is shared interchangeably in every week. The online learning is done within four days with five to six hours while offline learning (classroom learning) is held within two days with two up to three hours per day. This learning model combination is done in order to make the learners more enthusiastic and protect them from the outbreak.

"The combination of online and offline learning is done every week. Online learning is held in five to six hours for four days every week. In the meantime, offline learning model is executed only within two to three hours for two days. I and my friends felt so facilitated and motivated with this new exposure." (Deny, 2021)

Excerpt 15 


\begin{abstract}
"The hybrid learning has made me more enjoyable in learning. I felt much more facilitated and more advised. Online and offline learning are done every week with different time. Offline learning is done so as to make learners fun. Although these two things are posed, this aims to minimize the interaction, grasp new learning experience, and protect us from the Covid-19 virus." (Any, 2021)
\end{abstract}

Excerpt 16

The campus administrators also emphasize that they plan to go on this hybrid learning model in the learning process even the post-Covid-19 pandemic for the sake of learning effectiveness since they feel that this design seems suitable with the learners' learning needs:

"The campus administrators promise to continue this hybrid learning model. I will also be happy if it is continued. This makes me fun in learning English." (Deny, 2021)

Excerpt 17

"This hybrid learning model may be continued after the Covid-19 pandemic ends. The campus has ever noticed that this design has been in accordance with the learners' needs and will be implemented forever since this can boost learners' learning motivation and interests for learning English.” (Any, 2021)

\section{Excerpt 18}

In brief, the results of the study indicate three kinds of learning experiences had by the learners prior to and during the Covid-19 pandemic: face-to-face learning experiences prior to Covid-19, asynchronous learning experiences during Covid-19, and hybrid learning experiences during Covid-19. These multifaceted learning experiences give the learners aware that learning is not restricted offline but it can be online as well according to the situation, and that this also promote the learners to be not only cooperative, but also be independent and selfdirected learning.

\section{Discussion}

Nested in the poststructuralist look of language learning, this study has answered to the question of what are the learners' experiences learning English prior to and during Covid-19 pandemic. The findings have argued that the learners experience multifaceted learning process prior to and in the time of the Covid-19 pandemic: face-to-face learning experience prior to Covid-19 Pandemic, Asynchronous learning experience during Covid-19 Pandemic, and Hybrid learning experience during Covid19 pandemic. This current study has brought a new insight into the field of language learning, meaning that the learners have experienced face-to-face, asynchronous, and hybrid learning prior to and in the course of Covid-19. This dynamic and multifaceted learning process can be a potential source for the successful language learning process during and in the post pandemic era.
First and foremost, prior to Covid-19 pandemic, the learners gained face-to-face learning exposure. They, in this case, embraced an easier learning discussion, making them more accessible to interact and cooperate with their classmate since the learning process took place in the classroom. It is evident that offline learning is quite effective for promoting learners' competency in English. It is in line with a study conducted by (Damayanti \& Rachmah, 2020). They have looked into the learners' responses regarding their satisfaction with online and offline learning. They found that $62.5 \%$ of learners strongly agree that offline learning is effective for them; they feel that it can make them active in class, drive them more concentrated, able to easily interact with their classmate, provide them with more opportunities to ask about the materials they do not understand and enjoy the lesson (Damayanti \& Rachmah, 2020).

Alongside that, during the Covid-19 pandemic, the learning process run into a shit afterwards, this was initially from face-to-face learning to asynchronous learning process. It enforces the learners to adapt with online learning discussion. They, for the most part, learned English using WhatsApp, one of the popular instant messengers. On this occasion, the learning process of using WhatsApp run about two semesters in 2020 and drove them a new and independent experience which were never had before. Furthermore, using this app for language learning had brought advantages and disadvantages. The advantages they gained that learning English using WhatsApp led them to easy access since WhatsApp application had been possessed by them on their smartphone, and this also increased their self-confidence, motivation and willingness to learn such as sharing videos, PPT and links of YouTube have driven them to have selfregulated learning experience even though the drawbacks of using this instant messaging for learning existed such as redundant posts within the group and looking at the platform for too long, which results in boredom. It is apparent that learning using instant messaging like WhatsApp can go a long way in language learning (Awada, 2016; Alqahtani et al., 2018; Suryana, Hidantikarnillah \& Murwantono, 2021). It can, for example, improve the learners' confidence, motivation and willingness, and promote cooperative learning (Cetinkaya, 2017; Dahdal, 2020) even though the shortfall is available.

However, due to the continuity of Covid-19, the campus administrators increasingly contemplate the appropriate learning model for their learners. They attempt to create a new learning experience for the learners. They guessed that asynchronous learning which made use of WhatsApp was not so effective. The learners indeed need a new learning exposure, integrating some online learning applications in the learning process for better learning outcomes. In so doing, the process of learning is subsequently switched into a hybrid learning model, especially in the beginning of 2021. This model incorporates face-to-face learning and asynchronous 
online learning. In other words, the integration of face-toface learning and fully online instruction (Graham, 2005; Khan, 2005) is in effect in this case. In this regard, the learners experience English learning under hybrid learning model. Previously, they learned English in the face-to-face model and asynchronous model. However, this hybrid learning offered here requires the learners to consolidate traditional learning (face-to-face learning) and computer or mobile-assisted language learning (WhatsApp) in learning English.

This learning model has been conducted up to now. In fact, this new learning design has formed a vivid impression on them and has made them more enthusiastic and enjoyable in the learning process since this model pools face-to-face and online learning exposure. The learners, in this regard, experienced the learning process through some mobile applications, such as Google Classroom, Zoom, and WhatsApp coupled with offline learning model. Irizany (2002) has claimed that those who thrive in a hybrid learning discussion with tri-modal (i.e., video, sound, and text) seem to possess an individual study skill and enjoyment for working. The learners also stated that the learning process is highly individualized as well as flexible. It is asserted by Bärenfänger (2005) that the incorporation of self-directed learning or e-learning with classroom instruction promotes highly desirable development such as a more individualized, dynamic, flexible learning.

\section{Conclusion}

Since little works reports the snapshot of language learning experiences prior to and during the Covid-19 pandemic, the present study attempts to fill this empirical gap. It has reported that the learners have vast language learning experiences. They, as earlier stated, experienced face-to-face learning prior to Covid-19, asynchronous online learning during Covid-19 for about two semesters, and hybrid learning model during the Covid-19 pandemic which has run to date. These conditions spotlight that the learners have gone through multifaceted and dynamic learning exposure. In the face-to-face learning, the learners encountered their language learning in the classroom, while asynchronous learning had forced the learners to be actively involved in the mobile-assisted language learning situation. In the meantime, learners have also sampled hybrid learning model during the pandemic era, in which the learning process combined classroom-based and virtually-based learning with WhatsApp. Hence, the findings of the study have a deeper and strong implication for EFL teachers and learners who learn English in the time of Covid-19. The teachers might utilize the hybrid learning model for their learners and they will therefore be more enthusiastic in the learning process. This is done for the sake of the successful language learning, particularly in the EFL context. Further studies regarding the learners' experiences in learning English during the pandemic could be conducted in other areas. This might provide a more intensive result for the effectiveness in the learning process.

\section{Acknowledgement}

The researcher would like express his gratitude to Fery Ferdianto who has supported this research for publication and the anonymous reviewers of Elsya: Journal of English Language Studies for the insightful feedback of this paper.

\section{References}

Abdulrahman, T.Y., Basalama, N., Widodo, M.H. (2018). The Impact of Podcasts on EFL Students' Listening Comprehension. International Journal of English Linguistics, 8(6), 123-130.

Abidah, A., Hidayatullah, H.N., Simamora, R.M., Fehabutar, D., Mutakinati, L. (2020). The Impact of Covid -19 to Education and its Relation to the Phylosohpy of "Merdeka Belajar". Studies on Phylosohpy of Sciences and Education, 1(1), 38-49.

Abidin, M.J.Z., Rezaee, A.A., Abdullah, H.N., Singh, K.K.B. (2011). Learning Styles and Overall Academic Achievement in a Specific Educational System. International Journal of Humanities and Social Science, 1 (10), 143-152.

Ali, W. (2020). Online and Remote Learning in Higher Education Institutes: A Necessity in Light of Covid-19 Pandemic. Higher Education Studies, 10(3), 16-25.

Alqahtani, Bhaskar, Elumalay, \& Abumelha (2018). WhatsApp: An Online Platform for University-Level English Language Education. Arab World English Journal, 9(4), 108-121.

Annamalai, N. (2019). Using WhatsApp to Extend Learning in a Blended Classroom Enviroment. Teaching English with Technology, 19 (1), 3-20.

Atmojo, A., E., P. \& Nugroho, A. (2020). EFL Classes Must Go Online! Teaching Activities and Challenges during COVID-19 Pandemic in Indonesia. Register Journal, 13(1), 49-76.

Awada, G. (2016). Effects of WhatsApp on Critique Writing Proficiency and Perceptions toward Learning. Cogent Education, 3(1), 1-25.

Azmi, N. (2017). The Benefits of Using ICT in the EFL Classroom: From Perceived Utility to Potential Challenges. Journal of Educational and Social Research, 7 (1), 111-118.

Bärenfänger, O. (2005). Learning management: A new approach to structuring hybrid learning arrangements. Electronic Journal of Foreign Language Teaching, 2(2), 14-35. content/uploads/2020/09/v2n22005/baerenfaenger.pdf

Bubb, S. \& Jones, M. (2020). Learning from the COVID-19 home-schooling experience: Listening to pupils, parents/carers and teachers. Improving Schools, 00(0), $1-14$. 
Burnard P, Gill P, Stewart K, Treasure E, Chadwick B. Analyzing and presenting qualitative data. $\mathrm{Br}$ Dent $\mathrm{J}$ 2008;204 (8):429-32.

Carey, K. (2020). Is everybody ready for the big migration to online college? Actually, no. The New York Times. https://www.nytimes.com

Cetinkaya, A. (2017). The Impact of WhatsApp Use on Success in Education Process. International Review of Research in Open and Distributed Learning, 18(7), 5974.

Chandra, S.O. \& Yuyun, I. (2018). The Use of Google Translate in EFL Essay Writing. LLT Journal: A Journal on Language and Language Teaching, 21(2), 228-238.

Clandinin, D.J., \& Connelly, F.M. (2000). Narrative inquiry: Experience and story in qualitative research. San Francisco: Jossey-Bass.

Creswell, J. W. (2005). Educational research: Planning, conducting, and evaluating quantitative and qualitative research. Upper Saddle River, New Jersey: Pearson Education, Inc.

Dahdal, S. (2020). Using the WhatsApp Social Media Application for Active Learning. Journal of Educational Technology, O(0), 1-11.

Damayanti, F.L. \& Rachmah, N. (2020). Effectiveness of Online vs Offline classes for EFL classroom: A case study in a higher education. Journal of English Teaching, Applied Linguistics, and Literature, 3(1), 1926.

Dharma, H.R.C., Asmarani, D., Dewi, U.P. (2017). Basic Japanese Grammar and Conversation e-learning through Skype and Zoom Online Application. Procedia: Computer Science, 116, 267-273.

Dhawan, S. (2020). Online Learning: A Panacea in the Time of COVID-19 Crisis. Journal of Educational Technology, 4(1), 5-22.

Djalante, R., Lassa, J., Setiamarga, D., Sudjatma, R., Indrawan, M., Haryanto, B., Mahfud, C., Sinapoy, M.S., Djalante, S., Rafliana, I., Gunawan, L.A., Surtiari, G.A.K., Warsilah, H. (2020). Review and analysis of current responses to COVID-19 in Indonesia: Period of January to March 2020. Progress in Disaster Science, 6, 1-9. Efriana, L. (2021). Problems of Online Learning during Covid-19 Pandemic in EFL Classroom and the Solution. JELITA: Journal of English Language Teaching and Literature, 2(1), 39-47.

Gashemi, B. \& Hashemi, M. (2011). ICT: New wave in English language learning/teaching. Procedia: Social and Behavioral Sciences, 15, 3098-3102.

Grabe \& Grabe. (2005). Integrating technology for meaningful learning. USA: Houghton Mifflin.

Graham, P. (2005). Classroom-Based Assessment: Changing Knowledge and Practice through Pre-service Teacher Education. Teaching and Teacher Education, 21(6), 607-621.
Hussein, J. (2020). Covid-19: What Implications for Sexual and Reproductive Health and Rights Globally?. Sexual and Reproductive Health Matters, 28(1), 1-5.

Idami, Z. (2018). Students' perception on the use of Liquid Crystal Display (LCD) projector in English Foreign Language (EFL) Classroom. Journal of Linguistics, Literature \& Language Teaching, 4(2), 36-52.

Irizany, R. (2002). Self-Efficacy \& Motivation Effects on Online Psychology Student Retention. USDLA Journal, 16(12), 55-64.

Islam, M. Z. (2021). Shift of English Literature Learning from Classroom to Online: Preferences and Attitude of Bangladeshi Undergraduate Students. Elsya : Journal of English Language Studies, 3(1), 1-7. https://doi.org/10.31849/elsya.v3i1.5869

Jena, P. K. (2020). Impact of Pandemic Covid-19 on Education in India. International Journal of Current Research, 12(7), 12582-12586.

Khan, B. H. (2005). Managing E-learning: Design, Delivery, Implementation and Evaluation. Hershey, PA: Information Science Publishing.

Kheirzadeh, S., \& Birgani, M.B. (2018). Exploring the Effectiveness of Blended Learning in Improving Reading Comprehension among Iranian EFL Students. Journal of Applied Linguistics and Language Research, 5(1), 106-120.

Kohnke, L. \& Moorhouse, B.L., (2020). Facilitating Synchronous Online Language Learning through Zoom. Relc Journal, 00(0), 1-6.

Konig, J., Jager-Biela, D.J., Glutsch, N. (2020). Adapting to online teaching during COVID-19 school closure: teacher education and teacher competence effects among early career teachers in Germany. European Journal of Teacher Education, 43(3), 608-622.

Lincoln, Y.S., \& Guba, E.G. (1985).Naturalistic inquiry. Newbury Park, CA: Sage Publication.

Liu, Y., Kuo, R., Shih, S. (2020). COVID-19: The first documented coronavirus pandemic in history. Biomedical Journal, 43(4): 328-333.

McBrien J. L., Cheng, R., Jones, P. (2009). Virtual spaces: Employing a synchronous online classroom to facilitate student engagement in online learning. Int Rev Res Open Distrib Learn. International review of research in open and distributed learning, 10(3), 1-16.

Miles, M.B., Huberman, \& Saldana, J. (2013). Qualitative Data Analysis. Thousand Oaks: Sage Publication.

Mishra, L., Gupta, D., \& Shree, A. (2020). Online TeachingLearning in Higher Education during Lockdown: Periode of Covid-19 pandemic. International Journal of Education Research Open, 1, 1-8.

Octaberlina, L.R., \& Muslimin, A.I. (2020). EFL Students Perspective towards Online Learning Barriers and Alternatives Using Moodle/Google Classroom during COVID-19 Pandemic. International Journal of Higher Education, 9(6), 1-9.

Osman, M.E. (2020). Global Impact of Covid-19 on education systems: The Emergency Remote Teaching 
at Sultan Qaboos University. Journal of Education for Teaching, 46(4), 1-9.

Polkinghorne, D. E. (2005). Language and meaning: Data collection in qualitative research. Journal of Counseling Psychology, 52(2), 137-145.

Putri, N. S. (2019). Kahoot Application in English Language Teaching (ELT) Context: An Alternative Learning Strategy. Elsya : Journal of English Language Studies, 1(1), $11-15$. https://doi.org/10.31849/elsya.v1i1.2488

Putri, S. E., Hamuddin, B., Nursafira, M. S., \& Derin, T. (2020). Discourse Analysis in E-Learning-Based Course Using Moodle Platform: An Experimental Design. REiLA : Journal of Research and Innovation in Language, 2(1), 19-26. https://doi.org/10.31849/reila.v2i1.3960

Saldana, J. (2015). The Coding Manual for Qualitative Researchers. London: Sage Publication.

Setyaningsih, E. (2020). Face-to-face or online learning: Students' perspectives on blended learning in Indonesia. Journal of English Language Studies, 5(1), $1-14$.

Shadiev, R. \& Yang, M. (2020). Review of Studies on Technology-Enhanced Language Learning and Teaching. Sustainibilty, 12, 1-22.

Singh, V. \& Thurman, A. (2019). How Many Ways Can We Define Online Learning? A Systematic Literature Review of Definitions of Online Learning (1988-2018). American Journal of Distance Education, 33(4), 289306.

Sulistyo, U. (2016). English Language Teaching and EFL Teachers Competence in Indonesia. Proceedings of the Fourth Internasional Seminar on English Language and Teaching.

Suprihatin, Istiqomah, L., Meilani, R.I., \& Khoiriyah (2020). Exploring the Emotions of Single International Students in Hong Kong Facing the COVID-19 Pandemic. Journal of International Students, 10(3), 91107.

Suryana, I., Hidantikarnillah, V., \& Murwantono, D. (2021). A Narrative Inquiry of Language Teachers' Perceptions and Experiences in Using WhatsApp during New Normal Post-Covid-19 Era. Edulite: Journal of English Education, Literature, and Culture, 6(1), 55-70.

Terhune, N.M. (2015). Language learning going global: linking teachers and learners via commercial Skypebased CMC. Computer Assisted Language Learning, 29(6), 1071-1089.

Yulia, Y. (2013). Teaching Challenges in Indonesia: Motivating Students and Teachers' Classroom Language. Indonesia Journal of Applied Linguistics, 3(1) 1-16. Print. 